FARKAS TAMÁS - SLÍZ MARIANN szerk., Tulajdonnevek és szótárak. ELTE Magyar Nyelvtudományi és Finnugor Intézet - Magyar Nyelvtudományi Társaság, Budapest, 2020. 53-62. DOI: 10.26546/4892373.4

\title{
Tulajdonnevek a tájszótárakban
}

1. A tanulmány tárgyáról, forrásairól. Hogy mit kezdenek a tájszótárak a tulajdonnevekkel, az elég esetlegesnek tünik. A legkövetkezetesebb és legegyszerübb megoldás a hárítás: ha a szerző vagy szerkesztő az előszóban, illetve a bevezetőben kijelenti, hogy tulajdonneveket nem vesz fel a szótárába. A nyitás a nevek felé azonban már sokféle lehet; ezeknek a megoldásoknak a típusait igyekszem körvonalazni, egy rövid jövőbeli kitekintéssel.

Külön foglalkozom a három fö tájszótártípus: az általános tájszótárak, a regionális szótárak és a tájszó-tárak névkezelésével. Az általános tájszótárakból mindet bevonom a vizsgálatba, a másik két kategóriában válogatok a müvek közül. (A tájszótárak állományát mintegy kéttucatnyira becsüljük, müfaji határaik azonban nem mindig élesek; még akkor sem, ha a címben szerepel a tájszótár megjelölés.) A szótárak után röviden kitérek - mintegy függelékszerüen - a nyelvjárási atlaszok névkezelésére is.

A névtani információk forrásai a szócikkeken kívül az előszók/bevezetők és bizonyos függelékek lehetnek. A bevezetők többnyire utalnak arra, hogy felvesz-e az adott mü tulajdonneveket a szócikkek közé, és ha igen, miféléket. Van azonban olyan szótár is, amely bár nyit a nevek felé, de erről a bevezetőben elmulaszt nyilatkozni. Emiatt nem kerülhettem el, hogy - előzetes tájékoztatás hiányában - egyszerüen átlapozzak bizonyos szótárakat.

2. Az általános tájszótárak tanúsága. Az általános tájszótárak közös jellemzője, hogy szóanyagukat az egész nyelvterületről gyüjtik, illetve közlik. A következőkben ezen müveket tárgyalom a tulajdonnevek kezelése szempontjából.

2.1. Magyar tájszótár (Tsz., Magyar Tudós Társaság 1838). Első tájszótárunkat, amelyet a Magyar Tudós Társaság jegyez, feltehetőleg DöBRENTEI GÁBOR és VÖRÖSMARTY MiHÁLY rendezte sajtó alá. Még nem előzte meg kidolgozott lexikográfiai koncepció, és ez a tulajdonnevek kezelésében is megmutatkozik: sem a DÖBRENTEI GÁBORtól való Előbeszéd, sem a SCHEDEL [TOLDY] FERENCtől származó Utóirat nem tér ki a kérdésre, de a mü tartalmaz hely- és személyneveket. Néhány szócikk a szótár elejéről (betühü közlésben):
Ábri, Abrahám, kicsinyitve. Székely szó Albisban. Szabó Elek.
Ábris, Ábrahám. Kemenesali szó, Vas várm. Lévai Lászó.
Bábi, Barbara vagy Biri. Kezdi széki szó. Szabó Elek.
Bencze, 1) Benedek; 2) nyúl. Kemenesali szó, Vas várm. Lévai Lászó.
Bera, Albert. Palócz szó. Szeder Fábián.
Bora, Boris, Borbála. Palócz szó. Szeder Fábián.

SZABÓ ELEK nemcsak a székely szók közzétételében serénykedett, hanem gyakran kalandos - Ázsiába vivő - magyarázatokat is illesztett a tulajdonnévi adatközlések végére. Lássunk erre is néhány szórakoztató példát: 
Bene, Dálnokban ezen nevezetet viselő katonák vagynak, - ázsiai származásu szó. Kezdi székben divatos. Szabó Elek.

Csernáton, két nevezetes falu ugyanazon völgyben és patak mellett Kezdi székben. Az ázsiai nagy tengerszigetek közül China felé egyiknek neve Ternatani. Kezdi széki szó. Szabó Elek.

Csia, nemes familia’ vezeték nevezete. Czofalván T. Lisznyóban. Chinának egy tenger-szeme Csiaonak neveztetik. Kezdi széki szó. Szabó Elek.

Csik, székely nemes, és katonaság' vidéke, a’ hol vagyon az első székely gyalog ns. regiment' stabja; fenyős erdős helyekkel és havasos hegyekkel körül kerített kies szép hely, - az, hol sokkal több a' szurok, mint a' méz. A' chinai birodalomnak kebelében termő fák között, viasz-termő fa is iratik, mellynek a’ neve Csikha, a’ fa viasz gyánta és szurok lévén; tehát az illyetén fa Csikha nevet viselve, Csíkban is az efféle fa tevén a' bővebbi lételt; - innen a' Csík nevezet sem csíktól jön le, a’ mely ottan nem is lehetett, nem lévén nádas tók; hanem a viaszt termő fákról, ’s következőleg ázsiai nevezetből."”

2.2. Magyar tájszótár (MTsz. 1-2, SZINNYEI szerk. 1898). SZINNYEI a szótár bevezetőjében a következőket írja: „Ezek [ti. az alak szerinti tájszavak] teszik a szótár főrészét, a mely után külön-külön jegyzékbe foglalva következnek: a dajkanyelv (gyermeknyelv) szavai, a keresztnevek nyelvjárási változatai, az állatok tulajdonnevei $\mathrm{s}$ az állat-hivogató és üzö szavak." (1: IV). Ezek a megígért függelékek azonban nem készültek el, a 2. kötetben sem találhatók.

2.3. Új magyar tájszótár (ÚMTsz. 1-5, B. LŐRINCZY főszerk. 1979-2010). A szótár előszava így nyilatkozik: „Tulajdonneveket és tulajdonnévi származékokat általában nem vettünk fel, kivéve a nyelvjárási jellegü csillagneveket, a tulajdonnévi eredetü növényés állatneveket (pl. bánfipál-alma, ilonabogár) és tárgy megnevezéseket (pl. árpádvilla, debreceni csengó). Tulajdonnévi címszónk csupán néhány van (pl. Derecske, Kossuth, Pilátus), ezeket érdekes és jellegzetes frazeológiai egységek miatt alakítottuk ki." (1: 12). Ezek közül a Derecske szócikkét idézem:

Derecske fn. Sz: Megjöttek Derecskéröl (Sarkad 793): dér borít mindent. || SzamSz.

2.4. Nagy magyar tájszótár (NMTsz., KISS G. főszerk. 2019). Az ÚMTsz.-hez hasonló, elhárító állásponton van legújabb általános tájszótárunk is: „Megjegyezzük, hogy gyüjtésünk a köznevekre terjedt ki, a korábbi tájszógyüjteményekben szép számmal található tulajdonneveket - például földrajzi neveket - nem vettük fel gyüjteményünkbe" (10). Tulajdonnévi eredetü köznevek azonban az ÚMTsz.-hez hasonlóan előfordulnak az NMTsz.-ben is (1. pl. az ilonabogár, katibogár, katalin, katalinka, katóka, katókabogár, katókavirág típusú tájszavakat).

3. A regionális szótárak tanúsága. A regionális szótárak a tájszavakon kívül köznyelvi szavakat is az állományukba vesznek, ha azok az adott táj vagy település szókincsének szerves részét alkotják. A következőkben e szempontból tárgyalom a vizsgálatra kiszemelt forrásmüveket. 
3.1. Szamosháti szótár (SzamSz. 1-2, CSÜRY 1935-1936). CSÜRY BÁlINT klasszikus tájszótára korát megelőző teljesítmény volt a két világháború között. Az ezer oldalt meghaladó két kötetével egy kistáj népi nyelvhasználatának reprezentatív gyüjteményét adja. (Kevés nyelvjáráskutató volt képes megközelíteni ezt a teljesítményt mennyiségi és minőségi szempontból.) A tulajdonnevek felvételét is melegen támogatta. Ezt írja:

„Különös tekintettel voltam a tulajdonnevekre s ezek közt a földrajzi nevekre. Szótáramban gazdag anyagot talál a kutató helynevekre, határrésznevekre vonatkozólag is. Íme egypár: Erge, Galambos-erge, Kútergéje, Sebes ásvány (ér és pataknevek), Daru-kiáltó, Ördöngös, Zsaró, Csató, Ölyü-szeg, Setét-szeg, Kender-átó, Tömeg, Ravaszodu, Láz, Gaz, Nagy-gaz, Varga-gaz, Kétrét-gaz, Harminc-öl, Öt-apróföld, Nyolc-apróföld, Három-ér, Három-hold, Hat-fa, Hat-hold, Húsz-tó stb. (határnevek).

A helység-, falu- és városnevek közt különös tekintettel voltam azokra, melyeket a nép a köznyelvi alaktól eltérően ejt, mint pl. Kórógy (Kóród), Majtiny (Majtény), Szakmár (Szatmár), Pettyin (Pettyén), Józsipháza (Józsefháza), Odorján (Adorján), Vároja (Szinyérváralja), Nomény Nominy (Namény) stb. A Szamosháton divatos keresztneveket becéző változataikkal egyetemben nemcsak nyelvi, hanem néprajzi érdekességüknél fogva is mind fölvettem. A családneveket már csak válogatva vettem föl. A gúnyneveket tanulságos voltuknál fogva szintén felöleltem.” (12.)

A nevek felvételének oka tehát lehet a kiejtésbeli eltérés, a morfológiai változatosság (pl. beceneveknél), a néprajzi vonatkozások vagy egyéb motivációs sajátságok (pl. gúnyneveknél). Példaként idézzük a Darukiáltó és a Kendereskert szócikkét:

Darukiáltó Darukijátóú hn. (Vizenyős, lápos hely, régen a darvak tanyája.) (Kölcse.)

Kendereskert Kendereskērt hn. (Szárazberek).

3.2. Ormánysági szótár (OrmSz., KERESZTES szerk. 1952). Az OrmSz.-nak sem a szótári hagyatékot jegyző KISS GÉZA Bevezetőjében, sem pedig a kéziratot sajtó alá rendező KERESZTES KÁLMÁN előszavában (A szerkesztő bevezetése) nem találtam érdemi kitérőt a tulajdonnevek kezelésére. Hogy mégis vannak a szótárban ilyen szócikkek, arról az átlapozáson kívül a bevezetések után álló (számozatlan oldalon található) rövidítésjegyzék tájékoztat. A lista élén rögtön két ilyet olvashatunk: „csn. = családnév”, „dn. = dülőnév”. Történeti adatok felhasználására utal a következő rövidítésfeloldás: „r. csn. = régi családnév; (1561-i dicalis jegyzékből, 1696-i dicalis adólajstromból, 1741-i conscriptio domestica[-]ból és az 1808-i Tanubizonyságtevő levélből kiírt családnevek).” Lássunk ezek után néhány tulajdonnévi szócikket:

Ádámbörce Ádámbörci dn. (földhát; Palkonya). Vö. b ö r c .

Almás dn. (Kórós, Csehi). L. F a rk a s - , N a g y -, V a d a 1 m á s .

Atak Középkori elpusztult falu. Vö. A t a k i m e ző, N a g y a t a k .

Babér Gyakori ökörnév (1. ö k ö r ).

Balázs szn. 'a nagyotakaró ember neve a közmondásokban, szólásokban': Úgy böcsü, mim Balázs a gatyáját. - Neki Balázs, lāt ád Isten 
(törik, szakad, ennek a dolognak menni kell)! Vö. B a lás. L. S z e n t B a lá z s .

Barahó r. csn. l. c s a lád.

Bárcás gyakori ökörnév (1. ö k ö r ).

Amint a példákból is látszik, a szócikkek közé kihalt falunevek és állatnevek is bekerültek, illetve a frazémák tulajdonnevei is címszóvá válhattak.

3.3. Szlavóniai (kórógyi) szótár (SzlavSz. 1-3, PENAVIN 1968-1978). PENAVIN OLGA mestere és példaképe CSÜRY BÁLINT volt, szótárának elöképe pedig a SzamSz. Bevezetőjében ezt írja: „A népnyelv egész szókincsének összegyüjtésére törekedtem, azaz felvettem a közszókat [ti. a köznyelvi szókat - J. D.] és a tájszókat is, éppen úgy, mint már Csüry Bálint tette a Szamosháti szótárban. [...] Indulatszókat, állathívogató és terelö szókat, földrajzi neveket, dülő neveket [!], utcaneveket, családneveket, csúfneveket, keresztneveket (becéző alakjukkal is) felvettem, noha nem törekedhettem teljességre, mert nagyon felduzzasztották volna a szótár anyagát, csak a valamilyen szempontból érdekesebbeket szemeltem ki.” (8.) Széles tehát a nevek merítési köre, változatos az anyag, emellett viszont a szemelvényesség dominál. Néhány példa a szócikkek közül:

Dakóbokra Dakóubokrả hn. Kórógyi határrész neve.

Dávidka Dáovityká Dáovitykó ${ }^{u}$ szn. „kis Dávid”.

Devetke Devetke szn. csúfnév Szentlászlón.

Dezsővőgyi Dezsővö ${ }^{\prime \prime} g y i$ hn. szentlászlói határrész neve.

Fiastyúk Fijästyúk Fijästik fn. „,csillagkép, a Pleiades része”.

Gyönyörü Gyönyörü Harasztiban a Kürtös család egyik ágának csúfneve.

György György férfi személynév (Gyurà, Gyurkà - a fiatalok beceneve, Gyuri fiatalok és öregek beceneve).

3.4. A moldvai magyar tájnyelv szótára (MMTnySz. I/1-2, II, PÉNTEK szerk. 2018). A szótár szerkesztője, PÉNTEK JÁNOS így helyezi el a művet a tájszótárak között: „Az MMTnySz. szándékom szerint a regionális szótáraknak abba a típusába tartozik, amelynek mintájaként a Szamosháti szótárat szokás említeni” (I/1: 7). Ugyanakkor már az Előszó első bekezdésében megjegyzi: „Az eredetileg »enciklopédikus« szándékot is szerényebbre kellett fognom. Be kellett látnom: ha nem számolok a realitásokkal, akkor számomra is - mint egy évszázada több elődöm számára - a szótár továbbra is terv marad, vagy az utánam következő nemzedék(ek)re testálom a folytatását” (I/1: 5).

Ami a nevek felvételét illeti: „A köznévi elemek mellett kisebb számban, szintén a források függvényében, tulajdonnevek is kerültek a szótárba: személynevek (családés keresztnevek, becenevek), helynevek, településnevek stb. Különösen a kicsinyítő és becéző formák miatt a keresztnevekre a CsángA. anyagának gyüjtése idején is fokozottabban odafigyeltek, hozzátartoznak az anyaghoz, nem tehettem meg, hogy lemondjak róluk.” (I/1: 9.) Míg a személynevekre a CsángA., addig a helynevekre föleg HALÁSZ PÉTER gyüjtései, idevágó publikációi szolgáltatták a forrást. (Erre a „Hn.” rövidítés feloldásakor is történik utalás a 10. lapon.) Lássunk néhány példát! 


\begin{abstract}
Albény (ált.) településnév; nume de localitate; place-name: Albeni. Megj. Bogdánfalva része.

Albert Álbert (Di), Albét (Esz) férfi kn. prenume bărb.; male forename. CsángSz.

Alexandru Álëkszándru (Tn) férfi kn.; prenume bărb.; male forename. Kics. Álëkszándruska. (Tn) HPHn.

Babos (Kr) csn.; nume de fam.; surname. Hn. Babosok szántó (Kr).
\end{abstract}

4. A tájszó-tárak tanúsága. Tájszótáraink legnagyobb és legváltozatosabb csoportját azok alkotják, amelyek - a szakirodalmi hagyományokat követve - megelégszenek a tájszónak minősíthető lexémák szótárazásával. A tulajdonnevek felvételét illetően három típusba sorolhatók (a határok lehetnek életlenek is).

4.1. Névkizáró szótárak. A legtisztább eset a nevek teljes kizárása. Ebbe a csoportba tartoznak például a következők: KISS JENÖ Mihályi tájszótára (MihTsz.), HEGEDÜS ATTILA Kisnémedi tájszótára (KisnTsz.), SzABÓ JÓzSEF és Sz. BozÓKI MARGIT Koppány menti tájszótára (KmTsz.) és PESTI JÁNOS Alsómocsoládi tájszótára (AmTsz.). A hárítások egyszerüek és egyértelműek, nemigen kívánnak illusztrációt. A lényeg: a neveknek névtárakban, névgyüjteményekben van a helyük.

4.2. Névbefogadó szótárak. A másik alaptípust a névbefogadó szótárak jelentik. Jól szemlélteti ezt IMRE SAMU Felsőőri tájszótára (FTsz.). Idézzük a nevekre vonatkozó állásfoglalását: „A közszavak mellett felvettem szótáramba néhány tulajdonnevet is. Így például olyan, Felsőőrben gyakori vagy legalábbis jól ismert családneveket, melyek bizonyos hangtani sajátságokat igen pregnánsan tükröznek, vagy meglehetősen szokatlan hangfejlődést mutatnak; pl.: Bedenëk 'Benedek', Pongorác 'Pongrácz', Adrán 'Adorján', Bukics 'Vukics', Prunnër 'Brunner' stb.' (13.)

A helynevekkel kapcsolatban IMRE SAMU megjegyzi, hogy azokat már publikálta, de a korábbi közlése nem volt teljes: „Ebben a közleményben azonban csak a határrészek elnevezései, a dülőnevek szerepelnek, a belső településsel kapcsolatos nevek (községrészek neve, utcanevek) nem. Szótáramba - mintegy pótlásként - felvettem ezeket az adatokat is. A népi utcanevek regisztrálását azért is fontosnak tartottam, mert néhány évvel ezelőtt az addigi házszámos rendszerrel szemben hivatalosan is megtörtént az utcák elnevezése, sajnálatos módon a helyi hagyományok szinte teljes kizárásával, egykét fordítástól eltekintve lényegében csupa német nevekkel. Így az eredeti népi magyar elnevezések egy-két nemzedéken belül minden bizonnyal teljesen feledésbe mennek. [...] Felvettem a szótárba egy-két egyéb földrajzi objektumnak, például hídnak az elnevezését is. Ezt pedig azért tartottam fontosnak, mert ezek a nevek régebben általános használatúak voltak, de a Pinka folyó szabályozásával, új mederbe való terelésével mint létesítmények megszüntek, s nevük is rövidesen el fog tünni." (13.)

A nyelvterület peremén, szigethelyzetben, erős asszimilációs folyamatok közepette érthető a nyelvi leletmentés fontossága, így az indokok nagyon hasonlóak, mint amit fentebb PÉNTEK JÁNOStól olvashattunk a moldvai magyar tájszótár bevezetőjében. Figyelembe kell venni továbbá azt a körülményt, hogy a 20. század 50-es, 60-as éveiben nem volt egyszerü dolog eljutni ezekre a nyelvszigetekre és ott kiterjedt gyüjtést végezni, 
majd az összegyült anyagot megfelelö módon tudományosan is közzétenni. Így minden efféle gyüjtés és közzététel - hézagossága ellenére - felbecsülhetetlen értékü.

4.3. Sajátos névbefogadó szótárak. A névbefogadó tájszó-tárak közé is sorolhatók, de sajátos alcsoportként is kezelhetők azok a müvek, amelyek névanyagát valamely eddig nem említett tényező (is) meghatározza.

4.3.1. Kiskanizsai szótár (KiskSz., MARKÓ 1981). MARKÓ IMRE LEHEL a szótárát átmeneti jellegü alkotásnak tekinti: „Szótáram [...] középhelyet foglal el a regionális teljes szótárak (CSÜRY BÁLINT, BÁLINT SÁNDOR) és a szorosan vett tájszótárak (IMRE SAMU) típusa között" (8). Az átmenetiség okaként (hogy ti. elég sok köznyelvivel megegyező szót is szerepeltet) a passzív gyüjtési módszert jelöli meg: „A majdnem négy esztendő alatt naponként, folyamatosan végeztem a gyüjtést. Ennyi idő alatt szavaknak a százezreit lehetne lejegyezni példamondatokkal együtt. Én azonban a passzív módszerrel való gyüjtést választottam. A kívülálló óvatossága késztetett erre, mivel a szókincs nem nyelvjárásomból való. Kerültem még a lehetőségét is annak, hogy kérdéseimnek nem megfelelö feltevésével, kiejtésemnek elütő jellegével megzavarjam mind a szemantikai, mind a fonetikai spontaneitást.” (7-8.) Feltehetőleg ez a gyüjtési alapelv határozza meg a tulajdonnevek kezelését is: ami a spontán diskurzusban felbukkan, szótári egység lehet, de célzott gyüjtést és feldolgozást a szerzőtől elvárni nem lehet. Idézzünk néhány tulajdonnévi szócikket:

Reza Rëza szn. a Teréz beceneve.

Szent György-nap Szen Györ-nap fn. szent György ünnepe (ápr. 24.). M e g j. Ezen a napon zöld ágat tüznek a kapura, mert akkor a boszorkányok nem tudnak a házba menni, s nem tudják az állatokat megrontani.

Szüzanya Szüzanya fn. Szüz Mária. Jaj Szüzanyám, në haggy el!

Tölös $\sim$ dn. a temető melletti erdőszél, régebben sok tölgyfa állt benne.

Új-hegy Uj-högy dn. a homokkomáromi szőlöhegy része.

Úrnapja Urnaptya fn. 'az oltári szentség ünnepe'. A is vütte az eget Urnaptyán.

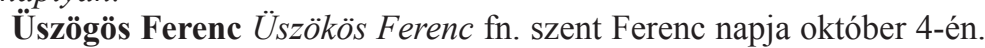
Üszökös Ferencko nëm szabad vetnyi, mer akko üszökös lëssz a búza.

Vadalmás Vadómás dn. Lazsnakpuszta melletti erdőrész.

A szerző az egyházi ünnepnapok neveit tulajdonnévnek tekinti, és a helyi nyelvjárási ejtésmód mellett különös figyelmet fordít a jeles napokhoz füződő néphagyományokra is.

4.3.2. Büki tájszótár (BükiTsz., BALOGH 2004¹ , 2016²). BALOGH LAJOS hosszú évtizedeken keresztül dolgozott szülöfaluja, a Vas megyei Bük tájszavainak összegyüjtésén. A munkát szótára első kiadása (2004) után sem hagyta abba, így a 2016-os bővített kiadás már jóval gazdagabb anyagot tartalmaz. Saját statisztikája szerint a 2824 szócikkből 250 a tulajdonnévi (BükiTsz. ${ }^{2}$ 30). Ez megközelíti a tíz százalékot, ami átlagon felüli névtani figyelmet jelent. Idézem a szótár bevezetőjének a tulajdonnevekre vonatkozó részét: „A tájszótárak többsége csak közszavakat tartalmaz, tulajdonneveket nem. Kivételesen eltértem ettől a gyakorlattól azzal, hogy bevettem a szótárba a környezö községek nevét is, elsősorban azért, mert a népi név hangalakjában és morfológiai szerkezetében sok esetben eltér a hivatalos névtől. Például a népi név Kál, a hivatalos név Sajtoskál, 
a népi név $B u ̈$, a hivatalos név $B o ̈$, így tehát valójában ezek a tulajdonnevek is tájszónak, táji névváltozatnak tekinthetők. Egyúttal megadom a települések hová? kérdésre felelő határozóragos alakját. Ezzel kívánom föltüntetni, hogy az adott település [ti. neve - J. D.] a helyi használatban külső vagy belső helyviszonyragot kap-e.” (24.)

A szerző azzal a megjegyzéssel, hogy a tulajdonnevek helyi ejtésmódja vagy morfológiai viselkedése számos regionalizmust hordozhat, így alkalmas lehet tájszói minősítésre, még nem hozott merőben új attitüdöt a magyar tájszótár-irodalomba, de azzal, hogy következetesen beépítette a szomszédos települések neveit, illetve mindegyiknek közölte a hová? kérdésre felelő ragos alakját, valószínüleg egyedülálló elvárással bővítette a nevek iránt nyitott tájszótárak módszertanát. Azzal is többletet rótt ki a maga számára, hogy a Vas megye földrajzi nevei című adattárból átemelte a Bükre vonatkozó dülöneveket, a történeti adatokkal és népi névmagyarázatokkal, megjegyzésekkel együtt (BükiTsz. ${ }^{2}$ 25). BALOGH LAJOS tehát a büki helynevek minél teljesebb körü és minél részletesebben dokumentált szerepeltetésével igyekezett bővíteni a szótárát.

4.3.3. Palóc tájszótár (PTsz., TÓTH 1978¹, 2007²). BALOGH LAJOShoz hasonlóan TÓTH IMRE is évtizedeken át gyarapította tájszógyüjteményét; Ipoly menti palóc tájszótára (1978) később bővítve, Palóc tájszótár címmel jelent meg (2007). A bevezetésben (20) részletesen foglalkozik müve tulajdonnévi anyagával. Viszonylagos teljességgel közli a kiemelt település, a szülöfalu, Bernecebaráti ragadványneveit és külterületi helyneveit. A helyneveket a hozzájuk tartozó történeti adatokkal, tárgyi és néprajzi megjegyzésekkel, a 70-es évek állapotát rögzítő múvelési ági besorolással HÁLA JÓZSEFtől vette át (Földrajzi nevek az Ipoly mentén). Erősen válogatva néhány más Ipoly menti település helynevei is a szótárba kerültek; ezek közlését valamilyen néprajzi vagy nyelvi érdekesség indokolja.

A többi tájszótártól eltérően nagy jelentőséget tulajdonít a ragadványneveknek; eredet és fajta (motiváció) szerint öt típusba sorolja őket, példákkal szemléltetve: „,keresztnévből keletkeztek: Albert, Laci, Misa stb., 2. vezetéknévből származók: Balyog, Hinö, Lajtos stb., 3. foglalkozásból vagy tisztségből adódtak: Bíró, Vótbírójék, Harangozó, illetve Bába, Tojásos, Tyúkász stb., 4. csúfnév: Csendes, Fingos, Fityisz stb., 5. lakóhelyet vagy származást jelölők: Fölysők, Budaj, Huntyi, Letovai stb. Akadnak ma már megfejthetetlen keletkezésü és hangalakú (esetleg eltorzított) ragadványnevek is.” (20.) Ugyanott névszociológiai, névlélektani megjegyzést is tesz: „A ragadványnevek túlnyomó többségét valóban megkülönböztetésre használják, s azok használatáért az érintettek nemigen neheztelnek.” „Végül egy-két jellegzetes családi név mellett szerepelnek még a szótárban azok a becenevek is, amelyek Ladó János Magyar utónévkönyvében nem találhatók."

5. Rövid kitekintés a nyelvatlaszokra. Tanulmányomnak nem szerves része a tájszótárakkal sok rokon vonást mutató másik fontos dialektológiai forráscsoportnak, a nyelvatlaszoknak a névtani szempontú szemlézése. Egy hasonló próbálkozásom már volt, amikor A romániai magyar nyelvjárások atlasza (RMNyA.) névállományát, névkezelési gyakorlatát tekintettem át (JUHÁSz 1999). Már akkor felmerült bennem, hogy módszeresen össze kellene gyüjteni minden nyelvatlasz tulajdonneveit. Ez a „feltérképezés" - a teljes címszókészlet számbavételével - időközben megtörtént SZABÓ PANNA doktori (PhD) értekezésében (2018), de még nem látott napvilágot, és részletes értékelése is várat magára. Addig is, amíg ez a célzott tanulmány meg nem születik, érdemes egy figyelemfelhívó pontban kitérni a témára. Lássuk először azt, hogy milyen névfajták milyen egyedekkel képviseltetik magukat a nyelvjárási atlaszokban! 
A tájszótárakkal ellentétben a helynevek jelenléte az atlaszokban csak jelképes: $M a$ ros, Kolozsváron, Kolozsvárra, Marosvásárhelyen, Marosvásárhelyre, Szamos. A hangtani realizációk felderítése mellett a Kolozsvár és a Marosvásárhely városnév a helyhatározóragok viselkedése, azaz a morfológia okán került a kérdőívbe.

A jóval nagyobb arányú személynévi jelenlét fő mozgatórugója is a morfológiai sajátságok egy részének rendszertani és táji jellegü feltárása. Az egyik ilyen nyelvtani részrendszer a kicsinyítés-becézés. A következő keresztnevek kicsinyítő-becéző alakjairól készültek térképek: András, Anna, Aurél, Béla, Erzsébet (Erzsi), Ferenc, Gizella, György (Gyuri), Gyula, Ilona, Irén, István (Pista), János (Jani), Jolán, József (Józsi), Júlia, Károly, Katalin (Kati, fiatal-idős megoszlásban is), Lajos, László, Magdolna, Margit, Mária (Mari), Mihály, Miklós, Pál, Péter, Sándor, Zoltán, Zsuzsanna.

A másik morfológiai részrendszer a nevek ragozása, jelezése (különös tekintettel a határozóragokra). Íme a példák: Erzsiék, Erzsiéké, Erzsiékhez, Erzsiéknél, Erzsiéktől, Erzsihez, Erzsinél, Erzsitöl, Ferenchez, Ferencnél, Ferenctöl, Ferihez, Ferinél, Galambosékhoz, Józsiék, Józsiéké, Józsiékhoz, Józsiéknál, Józsiéktól, Józsihoz, Józsinál, Józsitól, Mihályé, Mihálytól, Pistánál (okosabb, fiatalabb), Pistáék földje, Sándorékhoz, Sándoréknál, Sándoréktól, Terinél.

A ritkább tulajdonneveket egy napnév (Szent Heverdel napja) és néhány csillagnév (ill. égitestnév) képviseli: Esthajnalcsillag, Fiastyúk, Göncölszekér, Hajnalcsillag, Hold (ill. udvara van a Holdnak), Kaszás (Orion), Nagy Göncöl, Sarkcsillag, Tejút.

Ezek a térképlapok egyenként és tematikusan is vizsgálhatók. (A legtöbb az RMNyA.ból való.) A tájszótárakkal való összehasonlításra feltehetőleg a keresztnevek becealakjai kínálnak legtöbb lehetőséget.

6. Pillantás a jövőbe. A fenti, részben mintavételszerű szemlézés után hogyan lehet még szélesebb körü, lehetőleg teljességre törekvő névtani számbavételt elvégezni? Ennek nyilván több útja és módja lehetséges. A neveket mellőző tájszótárak kizárása után következhet egy hagyományos, „manuális” gyüjtés, amely az érintett szótárak átlapozásával először listázza a tulajdonnévi szócikkeket. A szócikkek „,beltartalma” rögzíthető akár hiánytalanul, betűhűen is, egy későbbi sokoldalú feldolgozás számára, de készülhet rögtön onomatodialektológiai adatbázis is, jól megtervezett szempontrendszer alapján. Ebben a hangalaki realizáció után a fő névfajták megjelölésétől kezdve a lokalizáláson át a névfajtákra jellemző paraméterek megadása (dülőneveknél pl. térszínforma, müvelési ág, hová? kérdésre felelő alak, becézőneveknél az alapnév stb.), a nyelvtörténeti adatok és a néprajzi, helytörténeti vonatkozások stb. rögzítése következne. A paraméterek száma és struktúrája folyamatosan bővíthető, alakítható.

A névtani adatbázis optimális esetben beilleszkedhet egy olyan egyetemesebb dialektológiai adatbázisba, amely minden tájszótár minden szócikkét feldolgozza. Ha ilyen létesülne, nyilván összhangba kellene hozni az általánosabb nyelvjárástani szempontokat, kategóriákat a névtaniakkal. Egy ilyen „összmagyar”, egyesített tájszótár körvonalait KISS JENŐ már fölvázolta (1. KISS J. 2008). A minden tájszótárra kiterjedő, kritikai elemeket is tartalmazó lexikográfiai értékelés egyik „,mellékterméke” lehetne egy segédlet a leendő tájszótárak összeállítói számára, hogy milyen kötelező és ajánlott részfeladatokat végezzenek el részben a gyüjtés, részben pedig a szerkesztés során, és milyen típushibákat kerüljenek el. (Ilyen módszertani észrevételekre és ajánlásokra 1. pl. KISS J. 1995, 1998; HEGEDÜS 1996.) 


\section{Felhasznált források}

AmTsz. = PeSTI JÁNOS, Alsómocsoládi tájszótár. [Alsómocsolád Község Önkormányzata stb.], Alsómocsolád, 2008.

BükiTsz. ${ }^{1}=$ BALOGH Lajos, Büki tájszótár. Vasi Szemle Szerkesztősége, Szombathely, 2004.

BükiTsz. ${ }^{2}$ = BALOGH LAJOS, Büki tájszótár. Bük Város Önkormányzata - Magyar Nyugat Könyvkiadó, Bük-Vasszilvágy, 2016.

FTsz. = IMRE SAMU, Felsőőri tájszótár. Akadémiai Kiadó, Budapest, 1973.

KiskSz. = MARKÓ IMre LeHEL, Kiskanizsai szótár. Akadémiai Kiadó, Budapest, 1981.

KisnTsz. $=$ HEGEDÜs ATTILA, Kisnémedi tájszótár. ELTE Magyar Nyelvtörténeti és Nyelvjárási Tanszék - MTA Nyelvtudományi Intézet, Budapest, 1992.

KmTsz. = SZABÓ JÓZSEF [- Sz. BOZÓKI MARGIT], Koppány menti tájszótár. Wosinsky Mór Megyei Múzeum, Szekszárd, 2000.

MihTsz. = Kiss JENÖ, Mihályi tájszótár (Rábaköz). Nyelvtudományi Értekezések 103. Akadémiai Kiadó, Budapest, 1979.

MMTnySz. = A moldvai magyar tájnyelv szótára. I/1. Moldvai magyar-közmagyar rész. A-K. I/2. L-Zs. II. Közmagyar - moldvai magyar rész. A-Zs. Szerk. PÉNTEK JÁNOS. Erdélyi MúzeumEgyesület, Kolozsvár, 2016-2018.

MTsz. = Magyar tájszótár 1-2. Szerk. SzINNYEI JóZSEF. Hornyánszky, Budapest, 1893-1901.

NMTsz. = Nagy magyar tájszótár. 55000 népies, tájnyelvi és archaikus szó magyarázata. Főszerk. KISS GÁBOR. Tinta Könyvkiadó, Budapest, 2019.

OrmSz. = Ormánysági szótár. KISS GÉZA szótári hagyatékából szerk. KERESZTES KÁLMÁN. Akadémiai Kiadó, Budapest, 1952.

PTsz. ${ }^{1}=$ TÓTH IMRE, Ipoly menti palóc tájszótár. Bernecebaráti és vidéke tájnyelve az 1930-1940-es évek fordulóján. A Magyar Nyelvtudományi Társaság Kiadványai 176. Magyar Nyelvtudományi Társaság, Budapest, 1987.

PTsz. ${ }^{2}$ = TÓTH IMRE, Palóc tájszótár. Az Ipoly menti palóc tájszótár 2., javított, bővített kiadása. Nap Kiadó, Budapest, 2007.

SzamSz. = CsÜRY BÁLINT, Szamosháti szótár 1-2. Magyar Nyelvtudományi Társaság, Budapest, $1935-1936$.

SzlavSz. = Penavin OlgA, Szlavóniai (kórógyi) szótár 1-3. Forum, Újvidék, 1968-1978.

Tsz. = Magyar tájszótár. A’ Magyar Tudós Társaság, Buda, 1838.

ÚMTsz. = Új magyar tájszótár 1-5. Főszerk. B. LŐRINCZY ÉVA. Akadémiai Kiadó, Budapest, 1979-2010.

\section{Hivatkozott irodalom}

HeGEDÜS ATTILA 1996. A tájszók szótárazásának néhány kérdése. Magyar Nyelv 92: 476-479.

JuHÁsz DEZSŐ 1999. A romániai magyar nyelvjárások atlasza névtudományi jelentőségéről. Névtani Értesitö 21: 395-400.

KISS JENŐ 1995. Észrevételek a hazai regionális lexikográfiáról. Magyar Nyelv 91: 170-178.

KISS JENŐ 1998. A tájszavak és a tájszótárak - régi kérdéskör, új problémák. Magyar Nyelvőr 122: $427-437$. 
KISS JENŐ 2008. Az első tájszóközlésektől az egyesített digitális tájszótárig. Magyar Nyelvőr 132: 27-36.

SZABÓ PANNA 2018. Nyelvföldrajzi vizsgálatok a magyar nyelvterület nyugati felén a dialektológiai atlaszok alapján. Doktori (PhD) értekezés. ELTE BTK, Budapest. Kézirat. https://doi. org/10.15476/ELTE.2018.071

JUHÁSZ DEZSÖ

ORCID: https://orcid.org/0000-0003-1508-9688

ELTE Eötvös Loránd Tudományegyetem

Bölcsészettudományi Kar

\section{DEZSő JuHÁsz, Proper names in Hungarian dialect dictionaries}

Roughly two dozen dictionaries of regional Hungarian exist, but the borders of the genre are fuzzy. The approaches these dictionaries employ in the handling of proper names are generally incidental, and changeable. The most consistent and simplest attitude is to omit them from the dictionary. In these cases, the author or editor states that proper names are not listed in the dictionary in the Preface or Foreword. When names are listed, they are handled in a variety of ways; it is these this study aims to summarise while briefly touching upon future possibilities. The approaches used in the three main types of regional dictionaries - general dialect dictionaries, dialect dictionaries of certain regions and dictionaries of dialect words - are examined separately. All published general dialect dictionaries are surveyed while the other two categories are examined through selected examples. The different approaches are illustrated through example entries. The majority of entries for proper names contain micro-toponyms, while some contain anthroponyms including family names and nicknames. Rarely the names of animals, stars or planetary bodies also appear. The examination of name dictionaries is followed by a short appendix providing an overview of how names are dealt with on language atlases. 